Eur. J. Clin. Chem. Clin. Biochem.

Vol. 32, 1994, pp. 337-340

(c) 1994 Walter de Gruyter \& Co.

Berlin $\cdot$ New York

\title{
Antibodies to Tamm-Horsfall Protein in Patients with Acute Pyelonephritis
}

\author{
By Jasminka Benković ${ }^{1}$, B. Jelaković ${ }^{2}$ and Nada Čikeś ${ }^{2}$ \\ 1 Clinical Institute of Laboratory Diagnosis \\ 2 Institute of Immunology and Inflammatory Rheumatic Diseases \\ Zagreb Clinical Hospital, Zagreb University School of Medicine, Zagreb, Croatia
}

(Received June 9, 1993/January 10, 1994)

Summary: The role of antibodies to Tamm-Horsfall protein in the diagnosis of acute pyelonephritis was studied. Antibodies to Tamm-Horsfall protein were also determined in a group of normal subjects. Patients with acute pyelonephritis were divided into subgroups according to the concurrent presence of vesicoureteral reflux or nephrolithiasis. No statistically significant differences $(p>0.05)$ were observed for any class of antibodies (IgG, IgA and IgM) between the groups of healthy subjects and patients with acute pyelonephritis, regardless of the presence or absence of vesicoureteral reflux or nephrolithiasis. Values for different antibody classes showed that IgM antibodies were the most abundant in all the groups examined. A difference in the values of IgM relative to $\operatorname{IgA}$ and $\operatorname{IgG}$ antibodies was found to be statistically significant in the patient group only $(p<0.05)$. In patients with vesicoureteral reflux, there was no statistically significant difference $(p>0.05)$ between the values of IgM and of other antibody classes. In these patients, however, the highest values of all the three antibody classes were obtained, although these differences were also not statistically significant $(p>0.05)$. The results pointed to the need of further studies of the role of antibodies to Tamm-Horsfall protein in the diagnosis and pathogenesis of tubulointerstitial nephritis.

\section{Introduction}

Bacterial inflammation of the urinary tract is among the most common infections in the populations of developed countries (1). To date, the clinical picture alone has been used to diagnose acute pyelonephritis, with some degree of uncertainty, because the diagnostic procedures available are neither specific nor sensitive enough $(2-4)$. Tamm-Horsfall protein, found in the urine, mostly in the form of aggregates $\left(M_{\mathrm{r}} 7 \times 10^{6}\right)$ and partially in the form of subunits $\left(M_{\mathrm{r}} 80000\right)$, is synthesized in the epithelial cells of the ascending limb of Henles loop and in the proximal part of the distal tubule, i.e. in the part of the kidney most frequently damaged by pyelonephritis. Therefore, many authors $(5-8)$ have investigated the role of Tamm-Horsfall protein in the pathogenesis and diagnosis of urinary tract infections.

It has been postulated that pathophysiological alterations lead to the exposure of, and formation of antibodies to, Tamm-Horsfall protein. According to most authors (5, 9,
10), Tamm-Horsfall protein is "a hidden antigen" to the immune system.

Quite interesting is the demonstration of Tamm-Horsfall protein antibodies in serum from normal adults, children and newborns. This raises the question of the origin of the Tamm-Horsfall protein antibodies to Tamm-Horsfall protein autoantibodies, i.e. do they originate from the kidney or are they just antibodies to antigenically TammHorsfall protein-like proteins (11) non-specifically bound to Tamm-Horsfall protein?

At present, there is a controversy about the usefulness of the determination of antibodies to Tamm-Horsfall protein in the diagnosis of urinary tract infections $(5,6$, 12-17). Therefore, the aim of this study was to determine the Tamm-Horsfall protein antibodies in acute pyelonephritis patients divided into subgroups according to the concurrent presence of other conditions possibly contributing to the tubulointerstitial damage, such as nephrolithiasis and vesiculoureteral reflux. 


\section{Patients and Methods}

The study was carried out in a group of 26 patients (five males and 21 females) with the diagnosis of acute pyelonephritis made on the basis of physical and laboratory examinations. Clinical diagnosis was made according to the following criteria: significant bacteriuria $\left(>10^{5}\right.$ bacteria of the same strain per $1 \mu \mathrm{l}$ medium urine flow), erythrocyte sedimentation rate $>25 \mathrm{~mm} / \mathrm{h}$, body temperature $>38^{\circ} \mathrm{C}$, lumbar pain and sensitive succussion. Azotaemia was not present in any of the patients. Upon admission, all patients underwent radiological examinations (ultrasonography, infusion urography and miction cystourography). Eight patients had nephrolithiasis, and vesiculoureteral reflux, stage Il-III, was demonstrated in five female patients. A control group included 18 subjects who had never suffered from any renal disease and in whom the presence of acute urinary infection was ruled out by history and clinical examination.

\section{Isolation of Tamm-Horsfall protein}

Tamm-Horsfall protein was isolated from the urine of healthy adult males and females by multiple precipitation with $0.58 \mathrm{~mol} / \mathrm{l} \mathrm{NaCl}$ (18). The purity of isolated Tamm-Horsfall protein was tested by immunoelectrophoresis with a specific antiserum to Tamm-Horsfall protein (IgG fraction, Institute of Immunology, Zagreb) and a complete anti-human serum (Behring, Marburg, Germany). The protein concentration as measured by the method of Rieder was $1.08 \mathrm{~g} / \mathrm{l}$.

\section{ELISA}

The values of Tantm-Horsfall protein antibodies were determined by direct enzyme immunoassay (ELISA) according to the modified procedure proposed by Fasth et al. (6). Microtitre plates (Behring, Marburg, Germany) were coated with Tamm-Horsfall protein (10 $\mathrm{mg} / \mathrm{l}$ in phosphate buffered saline, $\mathrm{pH} 7.4$ ) for $1 \mathrm{~h}$ at $37^{\circ} \mathrm{C}$. After emptying the wells, human serum albumin $(1 \mathrm{~g} / 1$ in phosphate buffered saline, Behring, Marburg, Germany) was added and incubated for $1 \mathrm{~h}$ at $22^{\circ} \mathrm{C}$ to block the free binding sites. Thereafter, the plates were washed three times with phosphate buffered salineTween 20 and twice with distilled water. Serum samples $(100 \mu \mathrm{l})$ diluted with phosphate buffered saline-Tween 20, were added to each well (for the determination of IgA and IgG class antibodies, the dilution was $1: 5$, and for IgM class antibodies it was $1: 10$ ). After incubation for $1 \mathrm{~h}$ at $22^{\circ} \mathrm{C}$, the plates were washed three times with phosphate buffered saline-Tween 20 . Secondary antibodies labelled with alkaline phosphatase (anti-human IgG, IgA and IgM, Sigma, St. Louis, USA) were added, with previous dilution with phosphate buffered saline-Tween 20 (IgA, IgG and IgM class antibodies were diluted $1: 4000,1: 5000$ and $1: 25000$; respectively). After incubation for $1 \mathrm{~h}$ at $22^{\circ} \mathrm{C}$ and washing three times with phosphate buffered saline-Tween 20 , substrate solution ( $p$-nitrophenylphosphate, $1 \mathrm{~g} / \mathrm{l}$ in diethanolamine buffer, $\mathrm{pH} 9.8$, Sigma, St. Louis, USA), was added (100 $\mu \mathrm{l}$ per well). The plates were incubated for $1.5 \mathrm{~h}$ in the dark at $22^{\circ} \mathrm{C}$, and the colour development was stopped by the addition of $3 \mathrm{~mol} / \mathrm{l} \mathrm{NaOH}$ (Kemika, Zagreb), $200 \mu \mathrm{l}$ per well. Absorbances were read on a Behring ELISA analyser at a wavelength of $405 \mathrm{~nm}$.

The value of "blind test", i. e. the read for the Tamm-Horsfall protein-coated wells, and the value for unspecific binding, i.e. the absorbance for the wells to which secondary antibodies had been added, were determined for each microtitre plate. Both values were determined on three occasions and their means calculated. The value of Tamm-Horsfall protein antibodies was also determined on three occasions and the mean value of the three determinations was calculated.

The data thus obtained were statistically processed on a personal computer (PC AT) using Quickstat and Microstat programs. As the results showed unusual distributions for all antibody classes, the significance of the differences was determined by non-parametric methods, i. e. by the Mann-Whitney U test and Kruskal-Wallis test.

\section{Results}

Twenty-six patients (five males and 21 females) with the diagnosis of acute pyelonephritis were included in the study. The patients with vesiculoureteral reflux were younger (mean age, $30.6 \pm 19.5$ ) than either those with nephrolithiasis (mean age, $53.5 \pm 15.4$ ) or those with acute pyelonephritis without reflux and lithiasis (mean age, $43.5 \pm 20.6$ ). The age difference between the individual groups of patients was not statistically significant ( $p>0.05$ ). Vesiculoureteral reflux was present in four female patients, whereas nephrolithiasis was demonstrated in seven female patients and in one male patients. In most patients $(N=19)$, urinary tract infection was caused by Escherichia coli, in two female patients by Pseudomonas aeruginosa, and five patients had sterile urine on admission.

The values of antibodies to Tamm-Horsfall protein are shown in table 1.

No statistically signiificant differences were observed for any class of antibodies between the patients with acute pyelonephritis, with or without eoncurrent vesiculoureteral reflux or nephrolithiasis, and the normal subjects $(p>0.05)$. The highest values of all the three antibody classes were measured in the patients with acute pyelonephritis and vesiculoureteral reflux, but the difference was not statistically significant when compared with either healthy subjects $(p>0.05)$ or other patients $(p>0.05)$.

The results clearly showed the IgM antibody values to be the highest in all the groups of subjects. There was no statistically significant difference $(p>0.05)$ in the

Tab. 1 Values of Tamm-Horsfall protein antibodies in patients with acute pyelonephritis and in normal subjects.

\begin{tabular}{lllll}
\hline $\begin{array}{l}\text { Group of } \\
\text { subjects }\end{array}$ & $\begin{array}{l}\text { No. of } \\
\text { patients }\end{array}$ & $\begin{array}{l}\text { IgG } \\
\left(\mathrm{A}_{405 \mathrm{~nm}},\right. \\
\text { median) }\end{array}$ & $\begin{array}{l}\text { IgA } \\
\left(\mathrm{A}_{405 \mathrm{~nm}}\right. \\
\text { median) }\end{array}$ & $\begin{array}{l}\text { IgM } \\
\left(\mathrm{A}_{405 \mathrm{~nm}} \text {, }\right. \\
\text { median) }\end{array}$ \\
\hline $\begin{array}{l}\text { Normal } \\
\begin{array}{l}\text { Acute } \\
\text { pyelonephritis }\end{array}\end{array}$ & 18 & 0.06 & 0.03 & 0.16 \\
$\begin{array}{l}\text { Acute } \\
\text { pyelonephritis } \\
\text { and vesicoureteral } \\
\text { reflux }\end{array}$ & 4 & 0.02 & 0.04 & 0.26 \\
$\begin{array}{l}\text { Acute } \\
\text { pyelonephritis and } \\
\text { nephrolithiasis }\end{array}$ & 8 & 0.03 & 0.08 & 0.37 \\
\hline
\end{tabular}


values of IgG and IgA antibodies between the groups of healthy subjects and patients, but the patients with acute pyelonephritis had significantly higher IgM than IgG antibody values $(p<0.05)$. This difference was not statistically significant in the patients with vesiculoureteral reflux $(p>0.05)$.

\section{Discussion}

The diagnostic procedures currently used cannot differentiate between lower and upper urinary tract infections. As the question of the interstitial penetration by microorganisms in pyelonephritis cannot be answered with certainty, numerous authors have embarked upon the study of the role of Tamm-Horsfall protein antibodies in the diagnosis of urinary tract infections.

Determination of Tamm-Horsfall protein antibodies in sera from patients and healthy subjects, using the TammHorsfall protein polymer molecule isolated from the urine of normal subjects as an antigen, did not reveal any statistically significant differences between the two groups of subjects, suggesting that the determination of Tamm-Horsfall protein antibodies in serum is of no value in the diagnosis of acute pyelonephritis. Likewise, neither Lynn et al. (16) could demonstrate the usefulness of Tamm-Horsfall protein antibody determination in the diagnosis of urinary tract infections. Avis (17) has also reported similar results. In contrast, the results of other authors (12-15) suggest that the determination of Tamm-Horsfall protein antibodies might be valuable in the diagnosis of acute pyelonephritis.

Our results appear to be in agreement with the conclusions made by others $(5,10)$, stating that TammHorsfall protein is not directly related to the immune system. The highest values of antibodies to TammHorsfall protein were measured in the patients in whom vesiculoureteral reflux was also present, suggesting perhaps that in these patients, the immune system is directly stimulated by the Tamm-Horsfall protein polymer molecule penetrating the interstitium by intrarenal reflux from the urine. The difference relative to other patients and normal subjects was not statistically significant, probably due to the fact that vesiculoureterral reflux was present in four female patients only. These results are consistent with those reported by Fasth et al. (6), who observed significantly higher values of IgG and IgA antibody classes in the patients with acute pyelonephritis and vesiculoureteral reflux, compared with the patients with normal radiólogical findings.
In their subsequent studies, Fasth et al. (19) found low values for IgG, and explained this by Tamm-Horsfall protein antibody binding to Tamm-Horsfall protein deposits present in cicatrices, considering Tamm-Horsfall protein deposits to be a useful indicator of the formation of cicatrices in patients with vesiculoureteral reflux. However, the reported difference may have resulted from varying degrees of renal damage in the groups of patients observed, due to either different reflux stages, or to more frequent urinary tract infections.

The highest values for Tamm-Horsfall protein antibodies were measured in the test with secondary antibodies directed toward the IgM class of antibodies, which possibly also supports the above statement, i.e. that the Tamm-Horsfall protein polymer molecule is not directly exposed to the immune system. These results appear to suggest the binding of cross-reactive or "native" antibodies; in patients this would include the binding of cross-reactive antibodies against bacterial epitopes $(5,6)$ or epitopes of Tamm-Horsfall protein-like glycoproteins that may be changed or exposed to the immune system in inflammation $(9,20)$. Our results also support the hypothesis of the binding of cross-reactive antibodies, since differences in the values for IgM were statistically significant for the patient group only. The patients with vesiculoureteral reflux showed the highest values for all the three antibody classes, but the difference was not statistically significant, possibly due to direct immune system stimulation and the formation of IgG class antibodies. The difference in Tamm-Horsfall protein antibody values between the normal subjects and patients may have proved statistically significant if the test had been performed with Tamm-Horsfall protein isolated from the subjects with demonstrated urinary tract infection. Turner (21) observed changes in the glycation of some glycoproteins during infection, possibly suggesting changes in the Tamm-Horsfall protein molecule (e. g. changed proportion of sialic acid) during urinary tract infection. Therefore, determination of antibodies to Tamm-Horsfall protein isolated from the urine of patients with acute pyelonephritis might prove useful. The question would probably be better answered by the determination of antibodies to subunits of TammHorsfall protein isolated from patient urine, as it is quite certain that the Tamm-Horsfall protein polymer molecule is not in direct contact with the immune system (except in patients with vesiculoureteral reflux). As antibodies to bacterial antigens appear in urine earlier than in serum $(3,22)$, determination of Tamm-Horsfall protein antibodies in the urine appears to be potentially useful for the early diagnosis of acute pyelonephritis. 


\section{References}

1. Winter-Fudurić, I. (1991) Infekcije morkaćnog sustava. In: Interna Medicina (Vrhovac, B., Bakran, I., Granić, M., Jakšić, B., Labar, B. \& Vucelić, B., eds.) pp. 476-479, Naprijed, Zagreb.

2. Rubin, R., Tolkoff-Rubin, N. \& Cotran, R. (1986) Urinary tract infection, pyelonephritis and reflux nephropathy. In: The Kidney (Brenner, B. \& Rector, F., eds.) pp. 1085-1143, Saunders Co., Philadelphia.

3. Svanborg, C., de Man, P. \& Sandberg, T. (1991) Renal involvement in urinary tract infections. Kidney Int. 39, 541-549.

4. Pappas, P. (1991) Laboratory in diagnosis and management of urinary tract infections. Med. Clin. N. Am. 75, 313-332.

5. Marier, R., Fong, E., Jansen, M., Hodson, C., Richards, F. \& Andriole, C. (1987) Antibody to Tamm-Horsfall protein in patients with urinary tract obstruction and vesicoureteral reflux. J. Infect. Dis. 138, 781-789.

6. Fasth, A., Hanson, L., Jodal, U. \& Peterson, H. (1979) Autoantibodies to Tamm-Horsfall protein associated with urinary tract infection in girls. J. Paediatr. 95, 54-60.

7. Yin, P., He, B. \& Shong, Q. (1991) Urinary Tamm-Horsfall protein coating of free cells and its clinical diagnostic significance. Chung. hua. ko. tsa. chih. 30, 76-78 (Abstract).

8. Abrass, C. \& Laird, C. (1987) Tamm-Horsfall protein coating of free cells in urine. Am. J. Kidney Dis. 9, 44-50.

9. Kumar, S. \& Muchmore, A. (1990) Tamm-Horsfall protein Uromodulin (1950-1990). Kidney Int. 37, 1395-1401.

10. Sandberg, T. \& Fasth, A. (1987) Association between fever and the antibody response to Tamm-Horsfall protein in urinary tract infection. Scand. J. Urol. Nephrol. 21, 297-303.

11. Lynn, K. \& Marshall, D. (1981) The presence in serum of protein which are immunologically cross-reactive with TammHorsfall protein. Biochem. J. 194, 561-568.

12. Fasth, A., Begstson, U., Kaijser, B. \& Wieslander, J. (1981) Antibodies to Tamm-Horsfall protein associated with renal damage and urinary tract infections in adults. Kidney Int. 20, $500-504$.
13. Hanson, L., Fasth, A. \& Jodal, U. (1976) Autoantibodies to Tamm-Horsfall protein, a tool for diagnosing the level of urinary tract infection. Lancet $31,226-228$.

14. Larson, P., Fasth, A., Jodal, U., Akerlund, A. \& Eden, S. (1978) Urinary tract infections caused by Proteus mirabilis in children. Acta Paediatr. Scand. 67, 591-596.

15. Sheldon, C. \& Gonzales, R. (1984) Differentiation of upper and lower urinary tract infections: How and When. Med. Clin. N. Am. 68, 321-333.

16. Lynn, K., Bailey, R., Groufsky, A., Hunt, J., Bean, A. \& McGiven, A. (1984) Antibodies to the urinary Tamm-Horsfall glycoprotein in patients with urinary tract infection, reflux nephropathy, urinary substruction. Contr. Nephrol. 39, 296304.

17. Avis, P. (1984) Autoantibodies to Tamm-Horsfall glycoprotein: An artifact of technique? Contr. Nephrol. 39, 305-315.

18. Čvorišćec, D. (1984) Tạmm-Horsfall protein i značenje njegova odredjivanja u endemskoj nefropatiji. Doctoral dissertation, Zagreb University School of Medicine, Zagreb.

19. Fasth, A., Bjure, J., Hjaelmas, K., Jacobson, B. \& Jodal, U. (1984) Serum autoantibodies to Tamm-Horsfall protein and their relation to renal damage and glomerular filtration rate in children with urinary tract malformations. Contr. Nephrol. 39, 285-295.

20. Hoops, T. \& Rindler, M. (1991) Isolation of the cDNA encoding glycoprotein-2 (GP-2) in the major zymogen granule membrane protein cross-reactivity. J. Biol. Chem. 266, 4257-4263.

21. Turner, G. (1992) N-glycosylation of serum protein in disease and its investigation using lectins. Clin. Chim. Acta 208, $149-172$.

22: Measley, R. \& Levison, M. (1991) Host defense mechanisms in pathogenesis of urinary tract infections. Med. Clin. N. Am. $75,275-286$

Jasminka Benković, M: S.

Clinical Institute of Laboratory Diagnosis

Zagreb Clinical Hospital

Kišpatićeva 12

41000 Zagreb

Croatia 